\title{
Travellers and Communal Identity: Memory, Trauma and the Trope of Cultural Disappearance
}

\section{Mícheál Ó Haodha}

\section{Q OpenEdition \\ 1 Journals}

\section{Electronic version}

URL: http://journals.openedition.org/etudesirlandaises/2126

DOI: 10.4000/etudesirlandaises. 2126

ISSN: 2259-8863

\section{Publisher}

Presses universitaires de Rennes

\section{Printed version}

Date of publication: 30 June 2011

Number of pages: $43-57$

ISBN: 978-2-7535-1348-8

ISSN: 0183-973X

\section{Electronic reference}

Mícheál Ó Haodha, «Travellers and Communal Identity: Memory, Trauma and the Trope of Cultural Disappearance », Études irlandaises [Online], 36-1 | 2011, Online since 30 June 2013, connection on 20 April 2019. URL : http://journals.openedition.org/etudesirlandaises/2126 ; DOI : 10.4000/ etudesirlandaises. 2126

\footnotetext{
This text was automatically generated on 20 April 2019.

(c) Presses universitaires de Rennes
} 


\title{
Travellers and Communal Identity: Memory, Trauma and the Trope of Cultural Disappearance
}

\author{
Mícheál Ó Haodha
}

Autobiography is not something we simply read in a book; rather as a discourse of identity, delivered bit by bit, in the stories we tell about ourselves, day in and day out, autobiography structures our living ${ }^{1}$

We are a different people (Nan Joyce, author of Traveller [1985 $\left.]^{2}\right)$

1 This essay explores the manner whereby Irish Travellers, a long-ostracised cultural minority within Ireland are increasingly exploring their own representation within Irish public culture and the trauma induced by hundreds of years of discrimination and "Othering". It also investigates the manner whereby previous representations of Travellers and their history were effectively "written out" of the unitary version of Irish history that was promulgated upon independence in the early 1900 s.

Irish literature has a long history encompassing various tropes and representative discourses as relating to portrayals of Irish Travellers and the figure of the societal "outsider" generally. Indeed, as the long-established quintessential "outsider", the figure of the Traveller has long held a strong appeal for the Irish writer, in particular, a fascination which seems to have come into its own in English from the nineteenth century onwards, but one which is also evident in Irish language literature, oral and written, from a much earlier period. The modern era has seen writers as well-known and diverse as Synge, Yeats, Pádraic Ó Conaire, James Stephens, Liam O’Flaherty, John B. Keane, Bryan MacMahon, Jennifer Johnston and Richard Murphy employ Traveller characters and Traveller tropes, the vast majority of which have usually been made to fit a generic image. This image, a frequent mirror-type of the colonial "stage Irishman", has 
included that of the happy-go-lucky vagrant, the criminal, the drunk, the storyteller, the fighter and the outcast.

This literary confluence, often with negative and reductionist undertones as relating to such minorities, traverses the linguistic divide and is evident in both the literature produced in Irish (Gaelic) and Irish literature as written in English. Neither is the tradition of cultural "Othering" as relating to Travellers and other "liminal" or "outsider" groups one which can be divorced from the European literary context. It is only in recent decades that this discourse encompassing a received body of "lore" and stereotype with respect to Travellers and other migrants has begun to be challenged. An essential element in this counter-hegemonic challenge is the emergence of a small, but vibrant, canon of literature from within the Irish Traveller community itself, a literature the core impulse of which is frequently to counter the stale and stereotypical ways in which Travellers have been reproduced culturally, politically and ideologically until very recently. This "new" literature has a strong autobiographical or semi-autobiographical aspect to it and frequently attempts to bring Travellers in from the margins of public discourse. Its initial impulse is frequently to begin the process of deconstructing and usurping the monolith that is nineteenth and twentieth century Irish literary representations of Travellers and acting as a catalyst for the trauma induced by generations of "Othering" and ostracisation. In the postcolonial context that is characteristic of the Irish experience there is a strong argument to be made that the "generic" Western concept of the "Other" ${ }^{3 "}$ (i.e. Western history's denial of legitimacy to those individuals or cultures considered "Other", a discourse often invested in both materially and culturally by the colonizing powers of the West) simply assumed a different form upon Irish independence. What made this issue more complex in the Irish situation was the fact that the early twentieth century assertion of a new national identity as established through social differentiation and the articulation of the cultural "Other" was subsumed within a reverse ethnocentrism and reductive essentialism as part of the collective "ideation" that was the nascent Irish State or nation. Upon independence, the mishmash of cultural conditioning and labelling that had characterised Britain's colonial discourse and historical representation of the Irish e.g. the "Stage Irishman" and its collection of often-negative constructs - e.g. disorder, laziness, nomadism, begging, superstition - was simply transferred onto a new "Other" i.e. the Travellers.

4 Irish Travellers also became caught up in late nineteenth century debates concerning cultural and historical legitimacy, debates which frequently emerged outside the "native" Irish cultural milieu - e.g. the Anglo-Irish Victorianist, Orientalist and exoticist debates with respect to such questions as "authentic" Irishness. Such discourses exhibited strange historical congruences with the folklore-inspired forms of representation "from without" that categorised Romani/Roma (Gypsy) peoples in the late nineteenth and early twentieth centuries also, thereby positioning certain Irish literary categorizations of the Traveller "Other" within a broader European literary framework. The very process of modernity and the fate of immigrants and traditionally migrant peoples such as Travellers and Roma has continued to throw "into relief the contingency of all historical and political narratives of possession, origins and authorship... and... furnish affective rebukes to the complacent digestion of modernity's self-validating narratives"'. As with other traditionally migrant and diaspora peoples, Irish Travellers have seen witnessed the construction and permeation of a wide range of reductionist representations and 
stereotypes $^{5}$ in relation to their community, many of which have assumed the status of "fact" within Ireland's collective conscience. This reified discourse has traditionally been sustained through a series of unequal power relations and has formed itself into what Foucault termed a "regime of truth":

Each society has its regime of truth, its "general politics" of truth - that is, the types of discourse it accepts and makes function as true; the mechanisms and instances that enable one to distinguish true and false statements; the means by which each is sanctioned; the techniques and procedures accorded value in the acquisition of truth; the status of those who are charged with saying what counts as true ${ }^{6}$.

Mary Warde's memoir The Turn of the Hand (2009) is representative of a newly-emergent Traveller literature which serves to challenge the static and stereotypical way in which Travellers have been reproduced culturally, politically and ideologically, however.

It joins a fast-growing range of "life histories" and memoirs as produced by Irish Travellers themselves ${ }^{7}$ which provide a challenge on two fronts. Not only do they usurp the "traditional" Western mode of self-representation in historical terms, they are also characterised by a change of genre and approach, a "cultural turn" which facilitates a much wider range of diverse and multi-voiced texts ${ }^{8}$ to be heard.

While the confines of an essay prevent an in-depth exploration of this new cultural impetus, it is possible to recognise a number of themes which have emerged strongly in Travellers' autobiographical work, Mary Warde's included, themes encompassing issues as diverse as education, social inclusion, the fear of cultural (including linguistic) disappearance - to name but a few. The necessity to identify and usurp the negative stereotype tradition as relating to Travellers and as internalised by certain younger members of the community is also highlighted as is the importance of asserting cultural "difference" through Traveller self-expression. A strong emphasis is also placed on documenting instances of abuse and discrimination that led to Travellers' exclusion from the "majority" Irish population.

8 These writers frequently express bewilderment at the levels of prejudice exhibited by the Irish "settled" community towards Travellers and the ingrained nature of the stereotype tradition that is used to define them. They also exhibit a longing for the acceptance of nomadism, now frequently referred to as the "nomadic mindset", which is the kernel of Traveller identity. Such emotions are expressed in beautiful terms by Willy Cauley at the end of his memoir The Candlelight Painter (2004) when he says:

I was often asked if I was born again what would I like to be. Well, the first thing that comes to my mind is a swan. Yes, I know it's a strange thing to say but I have my own reasons for that answer. When you look at how peaceful a creature the swan is it seems to have no worries, it comes and goes as it pleases. And most of all it has rights. No one tells it to move on, no one tries to control it. So there you have it, my friend. Peace and freedom. That's all that I wish for in life. I came into this life peaceful and I intend to go peacefully. Just leaving my name behind me because no matter how tough your life is you always turn to God in the last minutes. It is said you must be like a child to enter the Kingdom of God. I wonder are there any halting sites for the Travellers up in Heaven because if there are they must be a sight better than the ones here on earth. The ones down here are like Long Kesh. And the walls keep getting higher and higher. Out of sight, out of mind. Every country has different peoples with different cultures. Who is to say that one people or one culture is better than the other? Who is to say that one people are more perfect than another? Are we not equal in the eyes of God? We are all just here on this earth for a very short while and isn't it better to leave this life with a clean 
soul, leaving your love behind to all mankind, the whole human race, your brothers and sisters. Stéis, The end'.

That a large element of this stereotype tradition has as much to do with ignorance of one another's cultures as it does with the maintenance of the social and cultural barriers between both the Traveller and settled communities is highlighted by both Joyce ${ }^{10}$ and Mary Warde ${ }^{11}$ in the very first pages of her life history:

We have lived beside each other for centuries on the small island that is called Ireland. They've lived within a stone's throw of one another - within spitting distance - and yet, there's never been as much misunderstanding and lack of communication. The same was true in the past and it's true to a certain extent even today. Because myth forms people's perceptions of one another. It's all they have, the only mirror where they can see the other who might be a stranger to them. We've heard all of the myths going back through the years. - The Travellers marry only their cousins. The Travellers are all robbers. They love fighting. They have plenty of money hidden away - buried in a box out the back. They are all secretive people - "as thick as thieves". They don't want to live in the same way as the rest of us - they have their own strange ways. They don't go into the hospital for the baby and they crowd in when somebody is dead so that the fighting can start. They are all "drop-outs" from the Famine fields. They're not Irish at all but came here once from another country ${ }^{12 "}$.

10 In order to combat the pervasive nature of the tradition that is stereotype reification books such as Maher's The Road to God Knows Where ${ }^{13}$ (1972), Nan Joyce's Traveller (1985), Pecker Dunne's Parley-Poet and Chanter (2004), William Cauley's The Candlelight Painter (2004) and Mary Warde's The Turn of the Hand (2009) all place a strong emphasis on the educational function which the oral tradition plays within the Traveller community. The effective dissemination of Traveller cultural values and history as elucidated through the oral tradition, makes the narratives and memoirs of this tiny minority an important mode of transmission for the community's "true" history as both Maher and Warde make clear: "[...] you must remember that storytelling is our only means of communication with the past. We on the road can't write our deeds, but we do remember them and pass them down faithfully by word of mouth ${ }^{14}$."

The older people would sit around the fires at night, talking about who was who and who was related to who and where the different generations of people and the names from. Who came from the West of Ireland and who didn't.

I was christened Mary Ellen Ward...and I was born in 1943 - in the fields of Athenry! I have three brothers and two sisters, there was another brother who died at a young age. When I was small we travelled around Galway city, Connemara and Ballinasloe where one of the oldest horse fairs in the world is held every year... the truth is that the oral tradition that was handed down to me by my family would be lost if I didn't commit it to writing... the myth is out there for years now that we were people who took to the road during the Famine... that the Irish Travellers were just "potato people"... That we were not "real" Travellers at all and that it was right and proper, and necessary even, to force us to "settle" down again... Those of us brought up in the real Irish Traveller tradition knew that this wasn't true. We knew it wasn't true but finding the official records that would back up our claims isn't easy... Interestingly enough I found out in relation to my own family and many of the extended families who were married into ours, that a large proportion of the information that the old Travellers said with regard to their origins and where the people said that they came from was one hundred per cent true. The oral tradition is more reliable than people give it credit for. Why wouldn't it be? When you think about it, why would somebody forget something that relates to their own family and their very own flesh-and-blood ${ }^{15}$ ? 
11 As with certain other traditionally-nomadic groups ${ }^{16}$, the written tradition may sometimes hold a certain ambiguity for Irish Travellers, some of whose members (in very recent generations anyway) were wary of the written articulation of cultural values or records or did not place a big emphasis on it. That the "authenticity" of the written record as an expression of the community's "true voice" is very important to many Travellers today is nevertheless highlighted:

It's an awful sad thing to have no education... If I knew how to write properly and had good spelling I wouldn't have done this book on tape. Anna Farmar [the book's editor] recorded it and wrote it out for me - if I wrote a book myself whoever published it would need a medal for bravery ${ }^{17}$ !

12 Traveller "life histories" are unique, in my view, for the searing honesty with which their authors approach "difficult" or fearful questions. A number of Traveller writers outline in blunt terms the emerging cultural threats that are both "settlement" and assimilation. This uncertainty as relating to the dangers of potential cultural disappearance is enshrined in the very title of Maher's book The Road to God Knows Where (1972) a book which was the first written Irish Traveller autobiography. Interestingly, it is two male members of the Traveller community, Cauley and Maher who are very overt in their intimations of possible assimilation and/or cultural loss: "You see, son, life is becoming more difficult and the road as a way of life is finished ${ }^{18}$..."

13 Cauley, a landscape painter by profession has spoken of the psychological difficulties induced by Travellers' forced settlement/assimilation in the absence of transient sites or any provision for those who wished to remain nomadic. He links the deliberate blocking off of traditional campsites as used on a seasonal basis by many generations of the same family with the obliteration of Travellers' "collective memory".

I wonder how many older Travellers became depressed because they weren't allowed to travel anymore? How many of them became depressed when they saw their traditional camping places being blocked up and they ended up drifting from the countryside into houses and the cities?... A number of my siblings who are now dead suffered from depression while they were alive. I think the city life may have had a lot to do with it. Freedom and travelling was in their blood and being cooped up in the city affected them and made them sick. I have heard that the same thing has happened to many other traditionally nomadic people who have been forced by circumstance to live in the cities - people like the Native American Indians and the Aborigines in Australia... Someday I will try and capture this misery in a painting. I will get a huge canvas, the biggest one I can find, and when the painting is done I will show it to the press and the government so as to make a statement to them. "Look it, this is how the government ignored us back through time. This is how you hurt these peoples' minds then, a hurt that later changed into a depression. At a later stage you forced them into houses. You blocked up their roads." I will put all my energies into that painting. Everything ${ }^{19}$.

14 Much Traveller autobiography expresses incomprehension at the level of prejudice that is often directed against Travellers by certain sections of the "settled" community, the roots of which frequently lie in ignorance and fear. Both Dunne and Cauley describe an antiTraveller hatred that blighted their memories of childhood:

It is funny but no matter how hard you try you will remember to your dying day those moments when people were prejudiced towards you. Every human being wants to be respected....The worst part of prejudice like this is when your childhood innocence is destroyed by it. I remember seeing people shouting at us when I was a child. "The Tinker isn't wanted here, go away," and all the rest of it ${ }^{20}$. 
This hostility sometimes went well beyond "name-calling" and the use of language as recounted by Cauley :

I will never forget one incident that took place near the village of Oranmore, about seven miles from Galway city when I was only four years of age. We had no wagon at that time and we were camped in our lúbán's (tents) in against the side of a ditch... we made camp for the night my father left the horse into some farmer's field without asking permission. He should not have done that of course but the next thing we knew there were shouts outside our tents and we came out in the darkness to find a bunch of angry farmers standing around the camp with huge torches that were on fire. They told us to get out of the area or they would burn us out. I remember being very frightened. When you are a child and you are standing there in the darkness and all these angry faces around you roaring and shouting. It was like a scene from one of those films you see about the Ku Klux Klan and the way that they used to attack the black people in America once ${ }^{21}$.

Maher also admits to an incomprehension concerning the levels of prejudice and hostility as displayed against Travellers in Ireland: "You know... I keep thinking about people. I keep asking myself, why do people have to hate each other ${ }^{22}$ "?

How Travellers responded (often with great dignity) in the face of such "provocations" is described in the form of a short anecdote, as outlined in Mary Warde's recently-published autobiography The Turn of the Hand:

My father was standing at the square in Tuam in the late 60s or early 70s with this fella from the town who was always hanging around there with the lads. This fella never had much so my father used to give him a cigarette or buy him a pint every now and then. That is to say my father was earning a living but this fella was doing nothing. Only a corner-boy. They were talking and somebody mentioned a man who had died suddenly out the road only a few days before. They were wondering who the man that died was. "I didn't know him", one fella said. He didn't come to town that much, his wife mostly came. He only came in to the fair and the mart but other than that he was a country man. The other fella said "Ara, sure he was only the breed of a tinker!" My father thought about what the fella said and he said "Well this is one tinker that must go and earn a few bob for himself and he threw his leg on the bicycle and cycled off. And that fella wasn't getting no other pint or fag from him because he was throwing a slur on travelling people who earned their living and all he was good for was a corner-boy. So he never got another pint or a fag from my father! So that's the way it $\operatorname{was}^{23}$...

In addition to the jettisoning of reified imagery, recent Traveller writings call on younger Travellers to jettison their feelings of inferiority and for the "settled" Irish community to make themselves more aware of the minority in their midst:

I would like all the travelling children to have self-confidence and to grow up proud of what they are because they are very special people with their own traditions and their own way of life $^{24} \ldots$

I think that the Travelling people are the true Irish people of Ireland and no Travelling person should be ashamed of what we are. We should be proud of it because we came from real Irish people. Our ancestors fought for this country and they had to leave their homes just the same as I'm sure some of yours had to years ago...Now is the time for the politicians to stand up and realise that we are Irish people. We have a right to be in this country. We have a right to say where we want to live. We have a right to live the way we want to live and it's not up to anybody else to plan how we should live ${ }^{25}$.

19 Virtually the entire Traveller autobiographical canon challenges the way in which Travellers have traditionally been precluded from discussions of modern Ireland. This is unsurprising given that many canonical historical texts, by both nationalist and 
revisionist historians alike, have simply excluded all mention of Ireland's oldest minority. In the very few cases that Travellers are alluded to at all, they tend to be depicted primarily in the role of passive recipients of the historical process, a group whose perceived position as drop-outs - i.e. victims of colonial eviction and/or the Great Famine - rendered them uninterested in such issues as Irish nationalism or the fight for Independence or uninvolved in Irish history generally. As a consequence, perhaps, Traveller authors have been at pains to emphasize their Irishness and their critical role in the development of Irish cultural processes. Cauley cites the Irish predilection for genealogy and "Where are you from?" to provide a counter to the manner in which Travellers are ostracised in Irish society. He combines the Irish obsession with genealogy with a healthy sense of humour in an attempt to obviate the sense of bitterness that grips him when he dwells on the manner in which Travellers have been denied a place in the Irish historical "record":

Sometimes in this country they treat you like an alien because you are a Traveller... That's how bad-minded some people are towards Travellers... We Travellers are a different people so we stand out from the crowd. People think because we have a different culture that there is something wrong with us. It is sad but that is the way that life is. And the strangest thing of all is that Travelling people and settled people are often buried beside one another when we pass on. Is that the only time that we communicate with each other? You have Cauleys in this country for centuries, for example. There are Cauleys who are settled people and Cauleys who are Travelling people. Do you mean to tell me that the settled Cauleys and the Travelling Cauleys aren't related somewhere back along the line? of course they are. But so many settled people act as if we, the Travellers, never had any connection with them ${ }^{26} .$.

Some of this incomprehension and bitterness also has its roots in the denial of the roles Travellers played in historical agency particularly as relating to the various Irish struggles for independence, an omission which is highlighted in nearly every Traveller autobiography produced to date. Mary Warde describes the solidarity and inter-marriage between Travellers and "settled" people that occurred at times of national crisis, and rebellion against the British colonial forces that dominated Ireland for centuries. The following anecdote refers to the Irish rebellion of 1798 , a year which was frequently known as "The Year of the French":

I'm tracing back now, drawing my way back through the well of the years to where the only history is what is passed down - from gather to cam (father to son). This is oral history now because it's all that we Irish were left with for the many centuries. All that we had. And a Ward family member, a Traveller Ward - he fought at the Battle of Vinegar Hill. He fought in 1798, spilled blood in the place where the blood flowed like rain. And from death and destruction came rebirth - He met a girl named Brigid Keefe.

She was a settled girl one of the many women who were involved in the rebellion and often-forgotten. This girl named Brigid Keefe - with her brother and her father - went up to Vinegar Hill in Wexford to try and drive away the tyrants. And after the fighting the Irish had their secret meetings, their feasting and drinking and their tending to wounds. And Brigid Keefe met and married Patrick Ward who fought at Vinegar Hill. They married in the place which they then called the "hidden Church".

This underground church where they got married at dawn was outside Ross somewhere and the curlew was only making his way home in the early-morning when they were pronounced man and wife. The Catholics had to be careful about who they were then. They had to keep their religion to themselves and so too did the priests. Because the priests in those days were hunted from place to place by 
the occupier. The British were afraid of priest and teachers alike, and their power over the Irish people. How they might make the people rise up against them. And after they were married the newly-wed Wards continued on the road and came down around the west of Ireland where they had children. Sons and grandsons married then back into the other Travellers the other Wardes (Irish: Mac an Bháird - Son of the Bard) that were always travelling the roads then. And that's the way it went down until it came to my own generation ${ }^{27}$. Tans during the Irish War of Independence (1919-1921) is also recounted:

[...] my grandfather was up town one day and he heard from somebody else that the Tans were looking for a Republican and the Republican had gone into the pub ands he had a gun in his pocket. To avoid being taken, he had to get rid of this gun quickly and what he did was - he passed it over the counter to the woman that was behind the bar serving the drinks. And that woman was a quick thinker and she dropped it into the grate - into the black dirt of where the fire would be lit in the evenings. And this fella came out of the door of the pub and he was in a right panic. He was a cold sweat and he was doing his best to stay calm. And he saw my father on the way in and they passed a message between one another. He knew that my father was a staunch Republican and he said to him. "Well he's in the pub - the gun is in the grate and the place is surrounded and they're going to search it." So my grandfather who was always a very calm man. He said in as calm a voice as he could muster. "Alright where is it?" "It's in the ashes." "That's fine", he replied and he went in the door. And he did a lot of chimney-sweeping in his day and so he got his brushes and he went in and said to the bar manager who was serving the drinks. It was a lady who used to work in this pub at the time. I've come in to clean the chimney - is the ashes cold?

"Oh yes", said the women behind the bar. "There's no fire down since last night." She copped it straight away! She knew by the tone in his voice - people were able to say things with gestures and the intonations of their voice in those days. They had to be able to communicate in secret ways in those colonial and oppression days just so's they could survive. So the Tans came in and were searching the place for the gun and my grandfather was inside cleaning away, attaching his different size brushes and cleaning away. And although this chimney was always cleaned regularly my father made it appear as if it hadn't been cleaned for donkey's years! He made sure the soot went all over the place and he was saying to the customers as if warning them - "Keep back - it's an awful dirty chimney!" And as the ashes were coming out, he spotted the gun at the back of the chimney flue and he scooped the handgun and all into the soot bag that he always carried when chimney-sweeping. And then - when he was finished, he rolled up everything. Rolled up the canvas bag and the soot and the whole lot and he said - "Will I throw the soot out the back or will I bring it?" - "Oh, wherever you want Pat" the woman in the bar answered putting on a brave face - as the Tans were crawling all over the place, frustrated in their search. Up the stairs and down the stairs and below into the basement where the drinks were kept in storage and where the barrels of porter were always changed. "There'll be a pint here for you when you come back in so Pat", the manageress of the pub said as my father made for the back door calling out to her - "I'll dump it out the back" - as he went. So he dumped the bag and all over the wall where it was picked up by another fella - another Republican who was watching and waiting and hoping for the best. And that is how that gun got out of Walsh's and how the Republican was saved ${ }^{28}$.

Maher and Joyce both refer to the importance of oral tradition in Traveller culture and point to its importance in assigning themselves a "dinnseanchas" or a "sense of place" within Irish society. This sense of orality that has been passed down faithfully by "word of mouth" is set against the official or "written" history of Ireland which would assign to 
Travellers a place in the footnotes of Irish history, a place where if they are considered at all, it is only as helpless victims of poverty and dispossession, the detritus of colonialism and a tragic Irish past who are only a strange nuisance or anachronism in the modern nation-state. Maher cites the Traveller known as the doll-man - the strange, shaman-like figure with whom Maher has a dialogue regarding the position of Travellers in the modern world - as an exemplar of the challenge to the official or "establishment" view from the oral culture of those who tell their stories "from below" or from the margins of society: “...The written history is very warped in its composition and truth. The history that has come down through the travellers, however, is more than reliable. It is told night after night around camp fires ${ }^{29} . . . "$

There's the history of our country - Ireland - and the history of the Irish people and the history of those Irish people who were Travellers and half of it is still hidden to us. More than half - probably the most of the loaf. All the myths that the English had about the Irish and the Irish had each other - the settled people about Travellers and the other way around. And we're only beginning to see through the fog of memory now, to brush past the misty rain to see where the sunlight is breaking through. To find our own true history. And like every history it's a mix of legend and fact, one story added to another like the layering brick of a house and all we can do is build our own house and construct our history once more in the way that we see fit and true. In our own way ${ }^{30} \ldots$

The urbanisation of Ireland has proceeded apace in recent decades and younger Traveller writers have focussed on those aspects of modern Irish culture which continue to be keenly contested in the post-independent and increasingly multicultural Ireland of today - i.e. questions of identity, nationhood and cultural legitimacy. Women Travellers such as Joyce, Sweeney ${ }^{31}$, and Warde reject Travellers' alleged non-involvement in the course of Irish history and point to Travellers' agency in the political and social struggles that formed the Irish nation while the recent literature of male Travellers such as Cauley and Dunne has provided new insights into Traveller language and history which serve to challenge the perception that Travellers were/are always a homogenous group. As elucidated in these "life history" narratives Traveller identity is a "constructed" one, a fictitious identity which has evolved through the longstanding re-articulation of stereotypes with myth as its bulwark. Such Irish representations of the Other are by now deeply entrenched within a wide strata of cultural discourses, policies and politics and as this brief exploration of the emergent Traveller literary canon exemplifies, they necessitate a critical re-engagement with both the questions of identity and Irishness.

A new interrogation with the identity "constructs" that are "Irish" and "Traveller" is long overdue and would be particularly valuable in unearthing those rich and varied layers that have contributed to the fashioning of Irish identity in the post-colonial era. Any such exploration necessitates a re-engagement with the "liminal" aspects our culture, that "alterity within identity" which has intersignified with the construct that is Irish identity itself. Such an identity is as distinctive as it is contemporary. It is an identity analogous with Kristeva's poetic description of the "stranger" in our midst: "[...] the stranger is neither a race nor a nation [...] we are our own strangers - we are divided selves ${ }^{32}$." 


\section{NOTES}

1. Paul John Eakin, Living Autobiographically: How We Create Identity in Narrative, Ithaca, Cornell University Press, 2008, p. 4.

2. Nan Joyce, Traveller, Dublin, Farmar Publishing, 1985.

3. For references on this, see Michel Foucault: Language, Counter-memory, Practice: Selected Essays and Interviews (New York, Cornell University Press, 1977); "The Order of Discourse" in R. Yang (ed.), Untying the Text; (London, Routledge, 1981); The Archaelogy of Knowledge (London, Tavistock Press, 1984); The History of Sexuality, Volume 1: An Introduction (London, Allen Lane, 1985); The Use of Pleasure: The History of Sexuality, Volume 2 (London, Penguin, 1985), as well as Jacques Derrida: Writing and Difference (London, Routledge and Kegan Paul, 1978) and Edward Said: Orientalism (London, Penguin, 1978); Literature and Society (Baltimore, Johns Hopkins University Press, 1986); Culture and Imperialism (London, Chatto and Windus, 1993).

4. Eoin Flannery, "Rites of passage: migrancy and liminality in Colum McCann's Songdogs and This Side of Brightness" in Irish Studies Review, 16:1, February 2008, p. 1-17 (p. 2).

5. Cf. Mary Hayes, The Irish Traveller, Dublin, Liffey Press, 2004, and A. Bhreatnach, "Travellers and the print media: words and Irish identity" in Irish Studies Review, 6:3, 1998.

6. Michel Foucault, Language, Counter-memory, Practice: Selected Essays and Interviews, Ithaca/New York, Cornell University Press, 1977, p. 131.

7. E.g. Nan Joyce, Traveller (1985); N. Donohue, Nan: The Life of an Irish Travelling Woman, Dublin, A. and A. Farmar, 1986; W. Cauley (Au.) and M. Ó hAodha (Ed.), The Candlelight Painter, Dublin, A. and A. Farmar, 2004; P. Dunne, (Au.) and M. Ó hAodha (Ed.), Parley-Poet and Chanter: A Life of Pecker Dunne, Dublin, A. and A. Farmar, 2004; B. Gorman and P. Walsh, Bare Knuckle Fighter, Dublin, Maverick House, 2002.

8. As with the literature of many minorities this "life history" genre of literature is somewhat difficult to classify. Within the scholarly canon, this "new" literature almost certainly comes under the generic rubric that is postcolonial studies, although it has many attributes which would also assign it to such categories as Diaspora Studies, Migration Studies or indeed, Subaltern Studies. Its discourses are those which challenge traditional narrative incredulities and within the Irish context, it is a small and growing canon which clearly elides a range of complex experiences, both historical and contemporary, and makes for a more radical and multifaceted reading of the legacy that is every form of colonialism, neo-colonialism and post-colonialism.

9. William Cauley and Mícheál ó hAodha, The Candlelight Painter, p. 109.

10. Nan Joyce, Traveller, 1985.

11. Mary Warde and Mary Hayes, "The Turn of the Hand": A Memoir from the Irish Margins, Cambridge, Cambridge Scholars Publishing, 2009.

12. Ibid., p. 3.

13. Sean Maher, The Road to God Knows Where, Dublin, The Talbot Press, 1972.

14. Ibid., p. 68. 
15. Ibid., p. 120-122.

16. Unsurprisingly, given the attempted annihilation of their communities during the Holocaust - some of this "based" on written (genealogical) records, certain Roma and Sinti groups have previously expressed an ambivalence with respect to the act of writing as a form of collective or group memory. This dilemma with respect to the written world is expressed in terms that are both haunting and artistically-beautiful by the central character Papuska in Irish writer's Colum McCann's novel Zoli (2007).

17. Nan Joyce, Traveller, p. 95.

18. Sean Maher, The Road to God Knows Where, p. 100.

19. William Cauley and Mícheál Ó hAodha, The Candlelight Painter, p. 23-34.

20. Pecker Dunne and Mícheál ó hAodha, Parley-Poet and Chanter: A Life of Pecker Dunne, p. 37.

21. William Cauley and Mícheál ó hAodha, The Candlelight Painter, p. 52.

22. Sean Maher, The Road to God Knows Where, p. 101.

23. Mary Warde, "The Turn of the Hand...", p. 98.

24. Nan Joyce, Traveller, p. 118.

25. Traveller Margaret Sweeney in Jane Helleiner, Irish Travellers: Racism and the Politics of Culture, Toronto, University of Toronto Press, 2000, p. 127.

26. William Cauley and Mícheál Ó hAodha, The Candlelight Painter, p. 74, p. 93.

27. Mary Warde, “The Turn of the Hand...", p. 1.

28. Ibid., p. 72.

29. Sean Maher, The Road to God Knows Where, p. 97.

30. Mary Warde, “The Turn of the Hand...”, p. 9.

31. Sweeney (2000) cited in Jane Helleiner, op.cit., p. 245. This is a rebuttal to the alleged "drop-out" theory of Traveller origins and a re-articulation of Traveller origins and identity within the discourse which categorised the nascent Irish state.

32. Julia Kristeva, Strangers to Ourselves, New York, Columbia University Press, 1991, p. 268.

\section{ABSTRACTS}

Until now many representations of Travellers and their history have been "written out" of the unitary version of Irish history which was promulgated during the early 1900s and upon Irish independence. This essay explores the manner whereby Irish Travellers, a long-ostracised cultural minority within Ireland have initiated a counter-hegemonic challenge to the "Othering" discourses and tropes which have categorized them previous to this. Once viewed as the quintessential "outsider" this marginalizing discourse encompassed a received body of "lore" and a range of stereotypes with respect to Travellers and other migrants. Recent years have seen a challenge to this history of representation however. An essential element in this counter- 
hegemonic challenge is the emergence of a small, but vibrant, canon of literature from within the Irish Traveller community itself, a literature the core impulse of which counters the representational traditions of the past. This literature brings Travellers in from the margins of public discourse and counters the trauma induced by generations of "Othering", the longestablished reification of image as produced culturally, politically and ideologically.

Nombreuses sont les représentations des Travellers ou de leur histoire qui ont été « effacées » du récit unificateur de l'histoire irlandaise, tel qu'il fut énoncé dans les années 1900 et à partir de l'Indépendance irlandaise - et qui le sont encore à ce jour. Cet article s'intéresse à la manière dont les Travellers irlandais, minorité culturelle longtemps ostracisée, sont en train, en un mouvement anti-hégémonique, de questionner les discours qui les posent comme « autres » ainsi que les figures récurrentes qui ont longtemps été liées aux Travellers. Leur position par excellence « extérieure » et le discours marginalisant qui leur est associé envisageait les histoires transmises oralement et les stéréotypes comme le réceptacle de l'altérité des Travellers et des autres migrants. Au cours des dernières années, ceci a été soumis à un questionnement et un canon de la littérature Traveller se dessine, issu de cette communauté elle-même, qui vise essentiellement à interroger les représentations traditionnelles du passé. Tirée hors de la marge vers la sphère publique, la littérature Traveller élabore dorénavant une réflexion sur les effets traumatisants de cette ostracisation et sur les images culturelles, politiques et idéologiques véhiculées.

\section{INDEX}

Keywords: ethnic minorities, history of representations, national identity, travellers, public debate, trauma

Mots-clés: minorités ethniques, histoire des représentations, travellers, identité nationale, débat public, trauma

\section{AUTHOR}

\section{MÍCHEÁL Ó HAODHA}

University of Limerick 